the other, it must be regarded as an object of the communicative and pragmatic orientation of the creative the activity of the performer musician to create a new music product in the realities of contemporary history for him and the listeners. Thus, musical texts, as real or potential sound phenomena, become a form of existence of music-performing culture, and at the same time, a way of preserving and transmitting multifaceted musically decorated artistic information about the spiritual and musical world of society, which is embodied in epoch-making musical texts and remains forever.

\title{
References:
}

1. Kozarenko, O. (2013). Yarema Yakubyak yak pryklad cognityvnogo musicoznavtsya [Yarema Yakubyak as an example of a cognitive musicologist]. Lviv: Art series. (in Ukrainian)

2. Lysenko, O. (2017). Musichne vykonavstvo: genesis, kryterii, systema (Istorychno-teoretychnyi ta mysteztvosnavchyi aspect) [Musical Performance: Genesis, Categories, System (Historical-Theoretical and Artistic Aspect)]. Kiev: NAKKKiM. (in Ukrainian)

\section{METHODS OF ARTIFICIAL INTELLIGENCE IN THEORETICAL MUSICOLOGY: HISTORICAL AND CONTEMPORARY PROJECTIONS}

\section{Kateryna Fadyeyeva ${ }^{1}$}

DOI: https://doi.org/10.30525/978-9934-588-13-6-4

Analyzing the problem of the impact of the latest computer technologies on the processes of development of the musicology's theoretical base, it is important to note that Ukraine is the birthplace of early developments in the field of music informatics.

Since the mid-1980's at the Kyiv State Conservatory named after P.I.Tchaikovsky operated a scientific laboratory. The specifics of its work was related to the problems of providing computer courses into the musical theoretical disciplines, in particular, the polyphony course, which initially looked like a terminology database, and in the future - expanded in terms of creating an algorithms' catalog of structural sequences in fugue exposures from the WTK by J.S. Bach. They were reserched by Doctor of Arts, Professor of the Kyiv State Conservatoire Igor Pyaskovsky. The idea of

\footnotetext{
${ }^{1}$ Ukrainian National Tchaikovsky Academy of Music, Ukraine
} 
leading acoustic horizontal (translating polyphonic sound into a single-line notepad) was developed by Ukrainian musicologist Leonid Dys and subsequently spread to the field of computer audio synthesis. This was a foreshadowing of the ideas of spectral music that were being worked on at the Institute of the Coordination of Music and Acoustics at the Georges Pompidou Center in Paris (IRCAM). Systematic analytical studies have been conducted at the Kyiv Institute of Information Registration Problems since 1994 for the creation of an information retrieval system and a database in the field of academic music under the direction of Mikhaylo Sinkov, Doctor of Engineering.

In addition, the Information and Search System «Musical Folklore of Ukraine» was created at the Problematic Research Laboratory at the P.I.Tchaikovsky National Music Academy of Ukraine. Ideas of machine analysis of musical text were actively implemented by professor I. Pyaskovsky. In particular, he developed a method of machine analysis of the musical text on the massif of Armenian and Transcarpathian folk songs, as well as melodies of Ukrainian folk songs, named «dumy» («thoughts»).

The development of heuristic computer programs on the basis of artificial intelligence methods for the analysis of logical and constructive mechanisms of musical thinking of O. Skryabin, K. Shimanovsky, A. Schoenberg and M. Verykivsky (on the example of combinatorics of harmonic and textural elements of composers' piano works) examined the author of this article.

This is foremost connected with the time-consuming analysis of the most difficult text, and, most importantly, it also provided an opportunity to identify the most complex patterns of the composers' musical thinking.

In Ukraine, have emerged trends that prepared a theoretical base due to the need to computerize the composer's creative process. So, in the field of algorithmic composition we will note the composer Leonid Grabovsky, and in the field of spectral music (deducing from the unanimous timbre the whole polyphonic score graphics) - Alla Zagaykevych - representative of the young generation of Ukrainian composers.

Computer technologies are widely used in many elements of artistic culture, such as arranging popular music (timbre and rhythmic processing), graphic design, music video creation and more.

Summarizing, there are two trends in the development of computer technologies - the first, which is manifested in the purely technical support of the process of creating an artistic product in the context of mass culture, the second is related to synthesizing the complex text structures based on artificial intelligence methods. 
The synthesized material is a testament to the process of updating the musical language, that is an actual problem of the European art's development.

The formation of a wide variety of spectral sound couplings (with the closest combination of texture and timbre) is therefore characterized by significant structural complications and requires new computer technologies to structure and further enclose by the composer in a musical work [3].

Thus, the latest technologies of using artificial intelligence methods have greatly enriched the musicological theoretical base in a variety of directions, ranging from musical-acoustic aspects and ending with a deeper awareness of the musical thinking mechanisms, social and communicative functioning of musical art.

\section{References:}

1. Dys, L. I. (1980). Providna horizontal ta formy yiyi proyavu (do pytannya pro akustychnu sut muzychnoho tvoru) [The leading horizontal and its forms of expression (to the question of the acoustic essence of the musical work)]. Ukrayinske muzykoznavstvo [Ukrainian Musicology]. Vol. 15, pp. 142-155.

2. Zahaykevych, A. L. (2005). Apostol ukrayinskoho avanhardu [Apostle of the Ukrainian avant-garde]. Muzyka [The music]. No. 6, pp. 24-25.

3. Pyaskovsky, I. B. (2007). Perspektyvy rozvytku kompyuternoyi muzyky [Prospects for computer music development]. Doslidzhennya. Dosvid. Spohady. [Researches. Experience. Memoirs]. Vol. 7, pp. 31-41.

4. Fadyeyeva, K. V. (2005). Strukturnyy analiz faktury piznih fortepiannyh tvoriv O.M.Skryabina (z dosvidu kompyuternoho prohramuvannya) [Structural analysis of the invoice of late piano works by O. M. Skryabin (from the computer programming experience). Visnyk Derzhavnoyi akademiyi kerivnyh kadriv kultury $i$ mysteztv [Bulletin of the State Academy of Management Personnel of Culture and Arts]. No. 3, pp. 61-66. 